\title{
PRELIMINARY STUDIES ON BLOOD GROUPS OF EELS ANGUILLA ANGUILLA (L.)
}

\section{ORIENTACYJNE BADANIA NAD WYSTEPOWANIEM CECH GRUP KRWI U WEGORZY ANGUILLA ANGUILLA (L.)}

\author{
Department of Legal Medicine Pomeranian Medical Academy in Szczecin \\ and Institute of Ichthyology
}

\begin{abstract}
Presented are the initial results of studies on appear ance of blood group characteristics at European eels. No presence of iso-agglutinin was noted. It ascertained that the erythrocytes of certain eels show special agglutination by respective human serum and lactines.
\end{abstract}

\section{INTRODUCTION}

Some considerable literature on blood groups of fish exist already.Concise review of this problem presented C u s h i.n g (1964). In accessible Polish literature, we found only a report in this respect. S 1 ot a, R a p a c z and $\mathrm{St}$ e f a $\mathrm{n}$ (1970), through isoimmunization obtained the serum which permits to distinguish group of isoantigens at carp Cyprinus carpio L.

The prospect of blood group application to genetic characteristics of fish and the possibility of distinguishing of various population within the same species ( $\mathrm{Par}$ is h, 1964) contributed towards interest of blood group at fish.

The earliest scientific reports on blood groups of fish are connected with eels. $\mathrm{M} \mathrm{i} \mathrm{a} \mathrm{z} \mathrm{a} \mathrm{ki} \mathrm{in} 1930$ ascertained that serum of Japanese eels Anguilla japonica Temminck et Schlegel agglutinate human erythrocytes of 0 group; $\overline{\mathrm{S}} \mathrm{ug}$ is h i t a (1935), applying the eels serum as reagent, distinguished the group system Ee in relation to density of agglutination of human erythrocytes.

The serum of eels Anguilla anguilla (L.) investigated: Jons s o n (1944) [after Grubb (1949], Klein and Georgieff (1951) and $S$ ag a $n$ (1964) has ascertained the utility of eel serum as reagent for agglutination of human erythrocytes of group 0 .

The cnly known report on blood groups of eels is of S u y e h i r o (1949) (after Cus hi n g - 1964) who supplements that the isoantibodies appear in serum of Japanese eels Anguilla japonica.

In present work, are presented the initial results of studies on blood group characteristics of European eels Anguilla anguilla. 


\section{MATERIAL AND METHODS}

The eels used for experiment ranged between 500 and $1000 \mathrm{~g}$ in weight. From each eel, $2 \mathrm{ml}$ of blood was taken into each of two tubes; one tube was empty and in other was present the Simon's liquid. After rotary separation, the erythrocytes were stored in glicerol liquid. The serum after separation was frozen under temp. $-20^{\circ} \mathrm{C}$ (S e y f rie d o w a and $\mathrm{W}$ a 1 e w s ka, 1971). For defrozing of erythrocytes used serie of glicerol dilutions. Tests were performed on glass plates by using $3 \%$ suspension of eel erythrocytes in $0.85 \%$ so lution of sodium chloride and by adding one drop of erythrocyte to one drop of agglutinin. The results were taken in 5 and 10 minutes from moment the erythrocytes mixed with agglutinin. Density of agglutination denoted: ++++- complete agglutination; +++ - complete agglutination with agglutinin splitting; ++ - very strong agglutination but visible numberous papulas; + - noticeable agglutination. Lack of agglutination denoted with 0 .

Used as agglutinines were: eels serum, human serum of group 0 of titre $1 / 128$ anti-A and anti-B; serum of $B$ group of titre $1 / 128$ anti-A and serum of A group of titre 1/128 anti-B; two serums of AB group; animal serum and extracts from plant seeds. The extracts from plant seeds were prepared from seed powder by adding $9 \mathrm{ml}$ of physiological sodium chloride solution to each $1 \mathrm{~g}$ of powder. After 10 minutes shaking in room temperature, incubated them for ab. $12 \mathrm{hrs}$ under temp. $4^{\circ} \mathrm{C}$. The applied fito-agglutinines were from seeds of: Pisum sativum L., Vicia sativa L., Phaseolus vulgaris L., Laburnum alpinum L.

5 groups, each of 20 eels, were tested for presence of iso-agglutinines. The erythrocytes of 12 eels were tested with above-mentioned agglutinines.

\section{RESULTS}

1. Tests for presence of natural iso-agglutinines were performed in 5 groups, each of 20 eels, by cross-agglutination of erythrocytes from each individual with serum of particular specimen.

The tests performed on 100 eels in 5 groups did not show in any serum the iso-agglutinines for tested arythrocytes.

2 . The tests of eel erythrocytes with natural human and animal serum were performed on 12 eels. Results are presented on the enclosed plate (Fig.1).

The serum of 0 group specimen strongly agglutinated the erythrocytes of nearly all eels, with somehow weaker agglutination of eels Nos 10, 9, 11 . Human serum of group A agglutinated slightly weaker the erythrocytes of eels than serum of group 0 , but somehow stronger than serum of group $B$. The serum of specimen of AB group, i.e. the serum without iso-agglutinines for human erythrocytes differed in their activity on erythrocytes of eels. The first of them agglutinated the erythrocytes of nearly all eels as strongly as serum of A-group specimen; in case of eel No. 12 agglutinated even stronger i.e., as strong as serum of 0 -group. Second serum of AB-groupagglutinated distinctly weaker the erythrocytes of all eels and did not agglutinate at all the erythrocytes of eels Nos 1 and 3 .

Animals serum in its properties of erythrocytes agglutination, principally did not differ from human serum of 0 -group; it also strongly agglutinated the 
erythrocytes of 6 eels and somehow weakly the remaining erythrocytes.

When considering the density of erythrocytes agglutination by used human and animal serum, distinct division may be noted. Distinguished may be the group of strong agglutination - An(a), to which are accounted the eels Nos 4, $5,6,7,8$ and the group of weak agglutination $-A n(b)$, to which are accounted the eels Nos 1,3 . These two groups do not comprise the erythrocytes of three eels Nos 9, 10, 11, which show the intermediate properties and could be assigned to third group - An (́c). To the same group of erythrocytes may be accounted the eels of intermediate density of agglutination, i.e. Nos 2, 12 .

3 . The tests of eel erythrocytes with extracts from seeds of Phaseolus. vulgaris $L$. proved very strong erythrocytes agglutination of twelve examined eels and of human control erythrocytes of groups $0, A_{1}, A_{2}$ and $B$ in extracts dilution of $1 / 10$. The density of agglutination was denoted as ++++. Extracts from seeds of Laburnum alpinum L. did not agglutinate the erythrocytes of any from twelve examined eels, but agglutinated human erythrocytes of groups 0 and $A_{2}$ and did not agglutinate the erythrocytes of $A_{1}$ group.

The tests performed with extracts from seeds of Pisum sativum L. and Vicia sativa L., are presented on the enclosed plate and divide the eels into two groups, viz.: a) groups comprising the eels Nos 6,8 of which the erythrocytes are strongly agglutinated by lactine from Pisum sativum L. but weakly agglutinated by extract from Vicia sativa. L.; b) group of remaining ten eels of which the erythrocytes are not agglutinated at all by lectine from seeds of Vicia sativa L. and by lactine from Pisum sativum L.

\begin{tabular}{|c|c|c|c|c|c|c|c|c|}
\hline \multirow{3}{*}{ 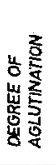 } & \multicolumn{6}{|c|}{ SERUM } & \multicolumn{2}{|c|}{ LECTINS } \\
\hline & \multicolumn{5}{|c|}{ OF HUMAN GROUP } & \multirow{2}{*}{ OF CATTLE } & \multirow{2}{*}{$\begin{array}{l}\text { PISUM } \\
\text { SATIVUM L. }\end{array}$} & \multirow{2}{*}{$\begin{array}{l}\text { VICIA } \\
\text { SATIVA L. }\end{array}$} \\
\hline & $O(\alpha \beta)$ & $B(\alpha)$ & $A(B)$ & $A B(1)$ & $A B(I I)$ & & & \\
\hline 4 & & & & & & & & \\
\hline 3 & & & & & & & & \\
\hline 2 & & & & & & & & \\
\hline 1 & & & & & & & & \\
\hline 0 & & & & & & & & \\
\hline & & & & & & & & \\
\hline
\end{tabular}

Fig. 1. 


\section{DISCUSSION}

Performed tests on appearance of blood groups at eels did not prove the iso-agglutinines by which the groups of eel blood could be distinguished. The results are contradictory to those given by $\mathrm{S} \mathrm{u} \mathrm{y} \mathrm{e} \mathrm{h} \mathrm{i} \mathrm{r} \mathrm{o} \mathrm{(1949)} \mathrm{after}$ $\mathrm{C} u$ s h i n $\mathrm{g}^{\prime}(1964)$ and require further tests on higher quantity of eels.

The presence of hetero-agglutinines in human and animal serum and noteable differences in density of erythrocytes agglutination of particular eel specimen, create the possibility in obtaining diagnostic serums for studies on blood groups of eels. An application of suitable human or animal serum may permit for division of eels intofollowing groups : a) group of strong agglutination - An (a), b) group of weak agglutination - An(b), c) group of intermediate characteristics -An(c). Similiar possibility is created by application of extracts from seeds of certain plants, e.g. from seeds of Phaseolus vulgarus L. The non-agglutination of eel erythrocytes by extracts from seeds of Laburnum alpinum $L_{\text {. }}$, is justified by similiar activity of this lactine and of eel serum on human erythrocytes of group 0. Certain possibilities on group distinguishing may be created by application of extract from seeds of Pisum sativum L. and of Vicia sativa L. Under application of these lactines the eels may be divided into two groups: a) group comprising only two eels of which the erythrocytes were agglutinated; b) group of remaining ten eels, of which the erythrocytes were not agglutinated at all, or agglutinated weakly.

The differences noted in density of eel erythrocytes agglutination by agglutinines presented in this report, may relate to group characteristics of eel blood, however ,the up to now studies do not permit to eliminate eventual connection with physiological condition of examined animals.

Carried-out presently, are the studies on hetero-immunization of guinea pigs, rabbits and of goats with erythrocytes of eels.

\section{REFERENCES}

C u s hing J.E., 1964: The Blood Groups of Marine Animals. Adv. Marine Biology; 2:85.

G r u b b R., 1949: Some Aspects of the Complexity at the Human ABO Groups. Acta Pathologica et Microbiologica Scandinavica, supl. 84.

K l e i $n$ H., Ge orgie $f$ G.P., 1951: Über ein Agglutinin im Serum des Aales. Zeitschr. Immunitatsforsch. u. exp. Therapie 108:395.

M i a z a ki S., 1930: The Serological Properties at Animal Blood in Relation to Isohemagglutination. XIII. Nagasaki-Skadoigaku-Haigakukyoshitu-gycho 2:542.

P a r ris h B.B., 1964: Notes on the Identification of Sub-Populations of Fish by Serological and Biochemical Methods, The Status of Techniques and Problems of Their Future Application. FAO Fisheries' Technical Paper No. 30, Roma: 1-9. 
S a g a n Z., 1964: Występowanie w przyrodzie aglutynin przeciw krwinkom ludzkim grupy 0. Dysertacja doktorska, mas zynopis,Uniwersytet Wrocławski. [Natural agglutinines against human arythrocytes of group 0. Doctorate's thesis, in typewriting, University of Wrocław].

S e y frie d o w a H., W a 1 e w s k a J., 1971: Technika niektórych badań serologicznych. Transfuzjologia kliniczna; [Technics of certain serological tests. Clinical transfusiology].226 PZWL, Warszawa.

S łot a E., R a p a c z J., S t ef a n J., 1970: Wstępne badania nad grupami krwi u karpia (Cyprinus carpio). [Preliminary studies on the blood groups in carp (Cyprinus carpio) ]. Zeszyty Probl. Post. Nauk Rol. 104: :71-78.

Sugis hit a S., 1935: Die neue biochemische Struktur und ihre Vererbung des menschlichen Blutes, welche durch den Haemagglutinationsgrad des Aalserums nachweissbar ist. I. Über die Klassifikation der zwei Gruppen (E - gross und e - klein) menschlicher Blutkörperchen mittels Aalserums. Zynzenkai. Zassi. 40.

\section{ORIENTACYJNE BADANIA NAD WYSTĘPOWANIEM CECH GRUPOWYCH KRWI U WEgGORZY. ANGUILLA ANGUILLA (L.)}

$$
\text { Streszczenie }
$$

1. Badanie krwi 100 węgorzy europejskich Anguilla anguilla (L.) nie wykazało obecności izoaglutynin.

2. Badanie krwinek 12 węgorzy przeprowadzone z surowicami ludzkimi, $z$ surowicą bydlęcą i wyciągiem $z$ Phaseolus vulgaris L. wykazały, iż krwinki.węgorzy są silnie zlepiane.

3. Zastosowanie odpowiednich surowic ludzkich lub bydlęcych może pozwolić na podział węgorzy na grupy: grupa silnej aglutynacji -An(a), grupa słabej aglutynacji - An(b), oraz grupa o pośrednich właściwościach -An(c).

4. Wyciągi z nasion Pisum sativum L. i Vicia sativa L. dzielą węgorze na dwie grupy: grupe, którejkrwinki są stosunkowo silnie aglutynowane i grupę, której krwinki prawie nie są aglutynowane.

\section{ВСТУПИТЕЛЬНЫЕ ИССЛЕДОВАННИЯ ПРОЯВЛЕНИЯ ГРУППОВЫХ ПРИВНАКОВ В КРОВИ УГРЯ АNGUILLA ANGUILIA ( I.)}

$$
P \text { e } 310 M e
$$

1. Исследования жрови 100 европейских угрей Anguilla anguilla ( I•) не обнаружили наличия изоатглютининов. 
2. Исследования кровяных телец 12 угрей, проведенные на человеческих сыворотках, на животной сыворотке и на экстракте Phaseolus valugaris I., показали, что кровяные тельца угря сильно склеиваются.

3. Применение соответствуюих сывороток, человеческих или животных, позволяет разделить угрей. на следующие группы: группа сильной агглютинации -An(a), группа слабой агтлютинации - $\mathrm{An}(\mathrm{b})$, а также·'руппа c промежуточными признакани -An(c).

4. Экстракты семян Pisum sativum и Vicia sativa разделяют угрей на две группы: группу, кровяные тельца которой являются сравнительно сильно склеенными, и группу, кровяные тельца которой почти не агглютинированы.

Address :

Received 26.XI.1971

Dr Zygmunt Sagan

Katedra i Zakład

Medycyny Sądowej PAN

Szczecin, Pl.Powstańców Wielkopolskich 72

Dr Cecylia Felińska

Instytut Ichtiologii AR

Szczecin, ul. Kazimierza Królewicza 4 Polska - Poland 